\title{
A Content Analysis of e-Government Practice in Indonesia: The Case of Pontianak Municipality
}

\author{
Syaiful Rahman ${ }^{\text {a }}$ * \\ ${ }^{a}$ Kecamatan Pontianak Barat, Pontianak, Kalimantan Barat
}

\section{INFORMASI ARTIKEL}

\section{Article history:}

Data submission : 10 January 2018

$1^{\text {st }}$ revision: 10 February 2018

Accepted: 16 March 2018

Available online: 12 May 2018

Keywords: e-Government, content analysis

\begin{abstract}
This paper aims to describee how the implementation of E-Government within public service provision in Pontianak City, West Kalimantan, Indonesia. This paper empirically investigated the implementation of e-Government by conducting a content analysis of the website portals developed by agencies under the jurisdiction and direction of Pontianak Municipality. The findings of the paper indicate that most of websites developed by government agencies vary in terms of e-government categories consisting of G2C, G2B, G2G, G2N, and G2E. In addition, those are in enhanced presence stage that means only employ eGovernment to provide dynamic, specialized and regularly updated information. Based on the results, this paper suggests that the government needs to develop standards for agencies in terms of website design to optimize and promote the sustainable development through the benefits offered by e-Government. Despite having an important contribution for academics and practitioners, this study produced rather limited results because the author conducted the research only on agencies in a local government sphere, that is Pontianak Municipality. Therefore, it is highly recommended for further studies to do the research on a wider scope.
\end{abstract}

2018 FIA UB. All rights reserved.

\section{Introduction}

One of the most significant current discussion in public sector is the implementation of Electronic Government, then called e-Government. It encourages government agencies and departments to use ICT (information and communication technology) tools and applications, internet and mobile devices to support good governance, strengthen existing relationships and build new partnerships within civil society (Ndou, 2004). A study of the United Nations (UN) corroborates that about 94 percent of the UN Member States are online (Eliassen \& Sitter, 2008) and offer an array of services to the citizens. As the central governments did, local governments have also equally adopted ICTs to transform the age-old mechanisms of governmentgovernment interaction (Ho, 2002; Moon, 2002). Many government agencies in developed countries have taken progressive steps toward the web and ICT use, adding coherence to all local activities on the Internet, widening local access and skills, opening up interactive services for local debates, and increasing the participation of citizens on promotion and management of the territory (Graham and Aurigi, 1997). However, The Electronic Government for Developing Countries report (ITU 2008) mentions that using ICT effectively to serve citizens online is a struggle for many governments, particularly in developing countries. Government organizations face great levels of uncertainty in developing and providing e-government services because of the complexity of the technology, deeply entrenched organizational routines, and great diversity in the acceptance of technology by individuals.

Regarding this topic, the Indonesian government has been conducting a massive improvement, related to the development and implementation of an electronic-based system of government. E-Government has been

* Corresponding author. Tel.: +62-341-553737; e-mail: syaifulrahman45@gmail.com 
established as an important part in the bureaucracy reform. It promises to overcome the digital disparity, improve the quality of services, increase economic growth, and maintain the sovereignity of the Republic of Indonesia. In local level, there are diversities regarding the development of e-Government due to the availability of ICT infrastructure, ICT human resources, quality of public services and economic growth rate varies from one place to another. In this paper, I opt for Pontianak Municipality to be a research object. Given Pontianak is one of cities becoming the award recipient for smart city program developed by PT. Telkom and Bandung Institute of Technology (ITB) in 2016 and 2017 respectively in which one of the categories is Digital Government Readiness.

The implementation of e-Government is also becoming an interesting theme among scholars, particularly in the field of public administration. Research on this issue have been considerably documented. Those research obviously provide a great deal of pivotal knowledge and insights through its findings, such as the explanation of the integration of online and offline services (Fan and Yang, 2015), factors which influence the use of ICTs to improve government efficiency, effectiveness and public service delivery (Reddick and Norris, 2013; Waller and Genius, 2015), a proposition of e-Government readiness within local government cases (Wahed Waheduzzaman and Shah J. Miah, 2015), the relationship between eGovernment adoption and citizen perspectives or public satisfaction (Athmay et. al., 2016; Wirtz and Kurtz, 2016). Nonetheless, most of research including those mentioned above rarely focus on the explanation of eGovernment by conducting a content analysis to websites developed by government agencies. As claimed by Nesta (Mulgan, 2014); one of the UK's innovation foundation, two of the most profound innovations of the last 50 years are internet and the world wide web.

This study is expected to provide a contribution to the existing literature on e-Government topic by filling the research gap as mentioned in the previous paragraph. In doing so, this study also seeks to answer two following research questions: What type of eGovernment is available? How is the current state of eGovernment practice in Pontianak?.

\section{Theory}

In the beginning of the 21 st century, there are has been an increasing amount of literature on eGovernment. This term means different things for different people. Some simply define e-Goverrnment as digital governmental information or a way of engaging in digital transactions with customers. For others it simply consists of the creation of a web site where information about political and governmental issues is presented. These narrow and poor understanding ways of defining and conceptualizing e-Government restrict the range of opportunities it offers. This is one of the reasons why many e-Government initiatives fail (Ndou, 2004). In effect, in its simplest definition, e-government refers to the use of digital technologies to transform government operations in order to improve effectiveness, efficiency and service delivery (Forman, 2005). It means that the more services available online and the more widespread their benefits, hence the greater the impact that e-government will have. In broader sense, Parajuli (2007) had summarized some definitions proposed by scholars (Elmagarmid and McIver, 2001; Norris, 2001; Netchaeva, 2002; Bhatnagar, 2004; Wyld, 2004) then he claimed that eGovernment or digital government is the use of ICT to promote and support citizen, business entity, and government agency participation for civic engagement and democratic responsiveness. Moreover, international organizations also seek to develop the most appropriate definition for e-Government term. The United Nations defined e-government as a permanent commitment by government to improve the relationship between private and public sectors through enhanced, cost-effective and efficient delivery of services, information, and knowledge (Tsekos, 2002). In addition, the Association of Southeast Asian Nations (ASEAN, 2004) defined it as the government playing a key role in the digital environment, not only by providing the right regulatory framework, but also by leading the way in using ICT for offering government services, and transforming the internal processes.

Furthermore, it is considered important to to measure various aspects of e-Government readiness that is the degree to which a community is prepared to participate in the networked world to evaluate its opportunities and challenges (Soliman, 2005). There are several studies that have identified various stages in the use of egovernment. Layne and Lee (2001) proposed a fourstage model of e-government. Those are online presence catalogue, transaction, vertical integration, and horizontal integration.

The United Nations and American Society for Public Administration (UNASPA, 2001) suggested an eGovernment model with five stages (UN's five-stage model) which are as follows:

a) Emerging presence: A single or a few independent government web sites provide formal but limited and static information;

b) Enhanced presence: Government web sites provide dynamic, specialized and regularly updated information;

c) Interactive presence: Government web sites act as a portal to connect users and service providers and the interaction takes place at a more sophisticated level;

d) Transactional presence: Users have the capability to conduct complete and secure transactions, such as renewing visas, obtaining passports and updating birth and death records through a single government web site; and

e) Seamless or fully integrated presence: Governments utilize a single and universal web site to provide a one-stop portal in which users can immediately and conveniently access all kinds of available services.

Furthermore, Fang (2002) summarized her research on e-Government with comparison and analysis of e- 
Government types and then concluded some characteristics of e-Government as follows:

Table 2.1. Characteristics of Types of E-Government

\begin{tabular}{|c|c|c|c|}
\hline Items & Information & $\begin{array}{c}\text { Communication } \\
\text { Online }\end{array}$ & Transaction \\
\hline $\begin{array}{l}\text { Government to } \\
\text { Citizen and } \\
\text { Citizen to } \\
\text { Government }\end{array}$ & $\begin{array}{l}\text { Information } \\
\text { requests of a } \\
\text { firm or the } \\
\text { citizen regarding } \\
\text { taxes, business } \\
\text { licences, } \\
\text { registers, laws, } \\
\text { political } \\
\text { programs, } \\
\text { administrative } \\
\text { responsibilities, } \\
\text { etc. }\end{array}$ & $\begin{array}{l}\text { Information } \\
\text { requests and } \\
\text { discussion } \\
\text { regarding admini- } \\
\text { strative processes } \\
\text { and products; } \\
\text { communication } \\
\text { with politicians, } \\
\text { authorities etc. }\end{array}$ & $\begin{array}{l}\text { Online } \\
\text { delivery of } \\
\text { service and } \\
\text { posting of } \\
\text { results; } \\
\text { electronic } \\
\text { voting, } \\
\text { providing } \\
\text { solution } \\
\text { online, and } \\
\text { participation } \\
\text { online, etc. }\end{array}$ \\
\hline $\begin{array}{l}\text { Government to } \\
\text { Business and } \\
\text { Business to } \\
\text { Government }\end{array}$ & $\begin{array}{l}\text { Information } \\
\text { requests of a } \\
\text { firm or the } \\
\text { citizen regarding } \\
\text { taxes, business } \\
\text { licences, } \\
\text { registers, laws, } \\
\text { business } \\
\text { programs, } \\
\text { business policy, } \\
\text { admini- strative } \\
\text { responsibilities, } \\
\text { etc. }\end{array}$ & $\begin{array}{l}\text { Information } \\
\text { requests and } \\
\text { discussion } \\
\text { regarding admini- } \\
\text { strative processes } \\
\text { for business and } \\
\text { products; } \\
\text { communication } \\
\text { with politicians, } \\
\text { authorities, etc. }\end{array}$ & $\begin{array}{l}\text { Online } \\
\text { delivery of } \\
\text { service and } \\
\text { posting of } \\
\text { results; } \\
\text { electronic } \\
\text { transactions of } \\
\text { accounting, e- } \\
\text { auditing, e- } \\
\text { procurement, } \\
\text { e-shopping, } \\
\text { etc. }\end{array}$ \\
\hline $\begin{array}{l}\text { Government to } \\
\text { Government }\end{array}$ & $\begin{array}{l}\text { Exchange of } \\
\text { information } \\
\text { among different } \\
\text { authorities and } \\
\text { different } \\
\text { hierarchical } \\
\text { levels, regarding } \\
\text { administra- tive } \\
\text { acts and laws, } \\
\text { policy making, } \\
\text { data, projects or } \\
\text { programs, } \\
\text { background } \\
\text { infor- mation to } \\
\text { decisions, etc. }\end{array}$ & $\begin{array}{l}\text { Information is } \\
\text { exchanged among } \\
\text { different } \\
\text { authorities and } \\
\text { different } \\
\text { hierarchical levels; } \\
\text { discussion fora; } \\
\text { communication in } \\
\text { negotiation and } \\
\text { decision making; } \\
\text { inter- action } \\
\text { regarding admini- } \\
\text { strative acts and } \\
\text { laws, projects or } \\
\text { programs, etc. }\end{array}$ & $\begin{array}{l}\text { Inter- } \\
\text { organisational } \\
\text { work- flow } \\
\text { and exchange } \\
\text { of data, } \\
\text { exchanging } \\
\text { policy and } \\
\text { solution } \\
\text { online, } \\
\text { information } \\
\text { and } \\
\text { knowledge } \\
\text { management, } \\
\text { etc. }\end{array}$ \\
\hline $\begin{array}{l}\text { Non Profit to } \\
\text { Government and } \\
\text { Government to } \\
\text { Non Profit }\end{array}$ & $\begin{array}{l}\text { Exchange of } \\
\text { information } \\
\text { regarding } \\
\text { administrative } \\
\text { acts, } \\
\text { administrative } \\
\text { policy, data, } \\
\text { registers, laws, } \\
\text { political } \\
\text { programs, } \\
\text { background } \\
\text { infor- mation to } \\
\text { decisions etc. }\end{array}$ & $\begin{array}{l}\text { Information is } \\
\text { exchanged among } \\
\text { different } \\
\text { organizations and } \\
\text { agencies; } \\
\text { discussion fora; } \\
\text { communication in } \\
\text { negotiation and } \\
\text { decision making; } \\
\text { interaction } \\
\text { regarding } \\
\text { administrative acts }\end{array}$ & $\begin{array}{l}\text { Intra- } \\
\text { organisational } \\
\text { work- flow, } \\
\text { and exchange } \\
\text { of policy and } \\
\text { solution, data, } \\
\text { inform- ation } \\
\text { and } \\
\text { knowledge } \\
\text { management, } \\
\text { etc. }\end{array}$ \\
\hline
\end{tabular}


(field notes) or broader entities (e.g. groups, cities). In this study, I collected data mainly from the website portals developed by government agencies under the jurisdiction and direction of Pontianak Municipality. This is to ascertain that the analysis is constructed on a reliable basis. In addition, secondary sources are used to enrich the quality of findings such as archival records or government documents. Article references were also searched further for additional relevant publications. Furthermore, this paper used employed a content analysis technique, as claimed by Steigleder (2008) with its different techniques of analysis and its methodological concept the content analysis is excellently adapted to analyze qualitatively collected material.

\section{Results and Discussion}

Before doing an analysis that will answer the research question, this paper shows the current status of e-Government in Indonesia. E-Government itself is a manifestation of national ICTs vision of the Government of Indonesia. First effort taken by the government to start developing e-Government in Indonesia is issuing some legal grounds consisting of Presidential Instruction No. 6/2001 on a five-year National Information and Communications Technology Action Plan for Indonesia, Presidential Decree No. 9/2003 concerning the ICT Coordinating Team (TKTI) and Presidential Instruction No. 3/2003 concerning National Policy on EGovernment Development. The latter rule is still the legal basis for promoting e-Government in Indonesia. Besides, the implementation of Law N. 11/2008 on Electronic Information and Transaction (ITE) that supports public transaction services also encourage the development of e-Government.

After established for more or less fifteen years, eGovernment is expected to reach a better level in terms of e-Government readiness. To get the information about that, we can see on the results of e-Government Survey carried out by The United Nations. Since 2001, the United Nations Department of Economic and Social Affairs (UNDESA) has published the United Nations EGovernment Survey. Now in its ninth edition, the Survey provides an analysis of progress in using egovernment and how it can support the realization of the internationally agreed development goals and help address emerging public administration issues.

Table 4.1. World e-Government Development Ranking : South-Eastern Asia

\begin{tabular}{|c|l|r|r|r|r|r|r|r|r|}
\hline \multirow{2}{*}{ No. Country } & & \multicolumn{6}{|c|}{ World e-Government Development Ranking } \\
\cline { 3 - 10 } & & 2003 & 2004 & 2005 & 2008 & 2010 & 2012 & 2014 & 2016 \\
\hline 1. & Brunei Darussalam & 55 & 63 & 73 & 87 & 68 & 54 & 86 & 83 \\
\hline 2. & Cambodia & 134 & 129 & 128 & 139 & 140 & 155 & 139 & 158 \\
\hline 3. & Indonesia & 70 & 85 & 96 & 106 & 109 & 97 & 106 & 116 \\
\hline 4. & Lao People's Dem. Rep. & 149 & 144 & 147 & 156 & 151 & 153 & 152 & 148 \\
\hline 5. & Malaysia & 43 & 42 & 43 & 34 & 32 & 40 & 52 & 60 \\
\hline 6. & Myanmar & 126 & 123 & 129 & 144 & 141 & 160 & 175 & 169 \\
\hline 7. & Philipines & 33 & 47 & 41 & 66 & 78 & 88 & 95 & 71 \\
\hline 8. & Singapore & 12 & 8 & 7 & 23 & 11 & 10 & 3 & 4 \\
\hline 9. & Thailand & 56 & 50 & 46 & 64 & 76 & 92 & 102 & 77 \\
\hline 10. & Timor Leste & 169 & 174 & 144 & 155 & 162 & 170 & 161 & 160 \\
\hline 11. & Vietnam & 97 & 112 & 105 & 91 & 90 & 83 & 99 & 89 \\
\hline
\end{tabular}

Table 4.2. e-Government Development Ranking in Indonesia (PeGI)

\begin{tabular}{|l|c|c|}
\hline \multicolumn{1}{|c|}{ Province } & Score & Category \\
\hline DKI Jakarta & 3.39 & Good \\
\hline Jawa Timur & 3.01 & Good \\
\hline Jawa Tengah & 2.64 & Good \\
\hline D.I.Yogyakarta & 2.66 & Good \\
\hline Jawa Barat & 3.07 & Good \\
\hline Kalimantan Timur & 2.52 & Good \\
\hline Gorontalo & 2.95 & Good \\
\hline Sumatera Utara & 2.62 & Good \\
\hline Nusa Tenggara Barat & 2.54 & Good \\
\hline Bangka Belitung & 2.9 & Good \\
\hline Bali & 2.63 & Good \\
\hline Jambi & 2.61 & Good \\
\hline Aceh & 2.51 & Good \\
\hline Sumatera Selatan & 2.33 & Poor \\
\hline Sumatera Barat & 2.01 & Poor \\
\hline Kalimantan Selatan & 1.88 & Poor \\
\hline Lampung & 1.76 & Poor \\
\hline Sulawesi Tengah & 1.73 & Poor \\
\hline Sulawesi Barat & 1.72 & Poor \\
\hline Bengkulu & 1.54 & Poor \\
\hline Soure:wwwomnf & & \\
\hline
\end{tabular}

Source : www.kominfo.go.id

Based on table 4.1, it can be clearly seen that Indonesia experiences a slight decrease from rank 70th in 2003 to 85th in 2004. Then, the figure drop significantly to rank 109th in 2010. In the last survey, Indonesia rank 116th E-government Development Index (EGDI), down 7 levels compared to 2010. This condition is still far below the countries in Southeast Asia such as Malaysia (rank 60th), Philippines (rank $71 \mathrm{st}$ ), and Brunei Darussalam (rank 83rd). The first to fifth position, respectively achieved by England, Australia, Republic of Korea, Singapore, and Finland. Meanwhile, the value of Indonesia's Online Service Index (OSI) and Telecommunication Infrastructure Index (TII) is also below the average in Southeast Asia. Indonesia is in the number 0.3623 OSI and 0.3016 TII, while the average OSI in Southeast Asia is 0.4598 and 0.306 in the TII. In contrast to OSI and TII, Indonesia's Human Capital Index (HCI) is already exceeding the regional average of Southeast Asia (0.6233) at 0.6796 . This certainly sets a challenge for Indonesia to improve the EGDI rankings in the years to come, in which the figures obtained are reflective of the condition of eGovernment implementation to ensure that public institutions are more inclusive, effective, accountable and transparent. 
Table 4.3. The Current State of e-Government Practice in Pontianak Municipality Sphere

\begin{tabular}{|c|c|c|c|c|c|c|c|}
\hline \multirow[b]{2}{*}{ No. } & \multirow{2}{*}{ Work Unit } & \multicolumn{5}{|c|}{ Stage in e-Government Model (UN's Model) } & \multirow{2}{*}{ Category } \\
\hline & & Emerging & Enhanced & Interactive & Transactional & \begin{tabular}{|c|} 
Fully \\
Integrated
\end{tabular} & \\
\hline 1 & Inspeltorat & & & & & & G2G \\
\hline 2 & Sekretariat DPRD & & & & & & G2G \\
\hline 3 & Satpol PP & & & & & & G2C, G2G, G2B, G2N, G2E \\
\hline 4 & BKPSDM & & & & & & G2G \\
\hline 5 & BKD & & & & & & G2C, G2G, G2B, G2N, G2E \\
\hline 6 & Bappeda & & & & & & G2C, G2G, G2B, G2N, G2E \\
\hline 7 & BPBD & & & & & & G2C, G2G, G2B, G2N, G2E \\
\hline 8 & DLH & & & & & & G2C, G2G, G2B, G2N, G2E \\
\hline 9 & Disdikbud & & & & & & G2C, G2G, G2B, G2N, G2E \\
\hline 10 & Dinas Kesehatan & & & & & & G2C, G2G, G2B, G2N, G2E \\
\hline 11 & Dis Perpustakaan & & & & & & G2C, G2G, G2B, G2N, G2E \\
\hline 12 & Disporapar & & & & & & G2C, G2G, G2B, G2N, G2E \\
\hline 13 & Dishub & & & & & & G2C, G2G, G2B, G2N, G2E \\
\hline 14 & DPUPR & & & & & & G2C, G2G, G2B, G2N, G2E \\
\hline 15 & Dinsos & & & & & & G2C, G2G, G2B, G2N, G2E \\
\hline 16 & Disdukcapil & & & & & & G2C, G2G, G2B, G2N, G2E \\
\hline 17 & DKUMP & & & & & & G2C, G2G, G2B, G2N, G2E \\
\hline 18 & Diskominfo & & & & & & G2C, G2G, G2B, G2N, G2E \\
\hline 19 & $\begin{array}{l}\text { Din.Perumahan dan } \\
\text { Permukiman }\end{array}$ & & & & & & G2C, G2G, G2B, G2N, G2E \\
\hline 20 & DPMTKPSP & & & & & & G2C, G2G, G2B, G2N, G2E \\
\hline 21 & Dinas Pertanian & & & & & & G2C, G2G, G2B, G2N, G2E \\
\hline 22 & Dinas PPKBPPPA & & & & & & G2C, G2G, G2B, G2N, G2E \\
\hline 23 & Kesbangpol & & & & & & G2C, G2G, G2B, G2N, G2E \\
\hline 24 & Secretariat KPU & & & & & & G2C, G2G, G2B, G2N, G2E \\
\hline 25 & \begin{tabular}{|l|} 
Kecamatan \\
Pontianak Tenggara
\end{tabular} & & & & & & G2C, G2G, G2B, G2N, G2E \\
\hline 26 & \begin{tabular}{|l|} 
Kecamatan \\
Pontianak Timur \\
\end{tabular} & & & & & & G2C, G2G, G2B, G2N, G2E \\
\hline 27 & $\begin{array}{l}\text { Kecamatan } \\
\text { Pontianak Barat }\end{array}$ & & & & & & G2C, G2G, G2B, G2N, G2E \\
\hline 28 & \begin{tabular}{|l|} 
Kecamatan \\
Pontianak Utara
\end{tabular} & & & & & & G2C, G2G, G2B, G2N, G2E \\
\hline 29 & \begin{tabular}{|l|} 
Kecamatan \\
Pontianak Selatan
\end{tabular} & & & & & & G2C, G2G, G2B, G2N, G2E \\
\hline 30 & $\begin{array}{l}\text { Kecamatan } \\
\text { Pontianak Kota }\end{array}$ & & & & & & G2C, G2G, G2B, G2N, G2E \\
\hline
\end{tabular}

Source : www.pontianakkota.go.id

At the local level, Indonesia has also conducted the assesment program to the implementation of eGovernment carried out by local governments. The program that is called PeGI (table 4.2), the ranking of eGovernment of Indonesia, is an annual activity undertaken by The Ministry of Communications and Information in order to evaluate the implementation of e-Government in government agencies at central, provincial, regency/city level objectively and comprehensively. It covers various aspects such as policy, institutional, infrastructure, application and planning. The aims of this program are as follows: provide a reference for the development and utilization of ICT in the government environment, provide an impetus for the increased use of ICT through a full, balanced and objective evaluation, and get information about the current condition of the utilization of ICT at the national level. However this kind of assessment has not been carried to all of local governments. Therefore, I 
decide to conduct the analysis by searching manually on the official website of Pontianak Municipality.

Table 4.3 presents the current state of websites developed by government agencies under jurisdiction and direction of Pontianak Municipality. I relate the data to the characteristics of e-Government claimed by Fang (2002) and then connect them with the stages of eGovernment suggested by the United Nations (2001). The data indicate that most of websites developed by government agencies can be classified into all of categories consisting of Government to Citizen and Citizen to Government, Government to Business and, Business to Government, Government to Government, Non Profit to Government, and Government to Non Profit, and Government to Employee Furthermore, most of them only employ e-Government to provide dynamic, specialized and regularly updated information. In other words, this evidence reflects that e-Government implementation in Pontianak Municipality sphere just reached stage two, that is enhanced presence. As mentioned in the theories, e-Government is obviously an important innovation within public sector. Therefore to get the best results of e-Government certainly much more needs to be done by the government.

\subsection{Pontianak Smartcity}

Pontianak is a city that successfully carry out public service. Based on Law 25/2009 on Public Service, Ombudsman award Pontianak Municipality as the best in public service in 2015 and 2016. In achieving this, implementation of e-services to realize the smartcity of Pontianak City should be appreciated. The success of Pontianak City is certainly supported by the quality of political leadership and human resources (ASN) Pontianak as an actor in providing public services. In 2017, as a form of transparent and responsive public service delivery, Pontianak Municipality created eGencil applications that provide various features, including: culinary, venue, event, food info, e-planning, e-budgetting and reporting (e-lawar). Through e-lawar feature, residents can report problems relating to public service in Pontianak and even they can photographing and uploading constraints faced, such as perforated roads. Public also can see directly the timeline of incoming reports. The report sent by community will go in Pontive Center -kind of media center developed by Communication and Information Agency- and forwarded to the relevant offices by the admin, then relevant offices will check immediately to the field. Online-based services as above is a form of Pontianak Mayor's commitment in making Pontianak as Smart City. Coupled with adequate human resources in Pontianak City Government, the realization of Pontianak Smart City can be achieved. Using ICT in governance is to make efficiency, acceleration, and ease in public service. The implementation of e-Government is also an effort to pick up the ball in fullfiling public needs. This also show that Pontianak Municipality can quickly adapt with the trend in which the number of people that now use smartphones and online services increases significantly.
In addition, as a follow-up to the hospital service report, Pontianak Municipal Government cooperated with startup Dokaloka to facilitate the public to check the doctor's schedule and to know the field of physician specialization. This service can also be used by patients to register online, without having to queue manually. Dokaloka also provides a drive to location feature that contains guidance for directions to the practice site and the hospital. The emergence of health Dokaloka is to meet public needs in which they still difficult to find out the fixed schedule of practice of general doctors, dentists, and specialties existing in Pontianak. Currently, Dokaloka has been working with three hospitals in Pontianak City to include a schedule of their doctors' practice, whether they are general practitioners, dentists, or specialists. Those are Untan Hospital (owned by Tanjungpura University), Antonius Hospital, and Mitra Medika Hospital. Along with e-Gencil, Dokaloka is also incorporated in the Pontianak Digital Stream community that supports the smart city government program developed PontianakMunicipality.

\section{Conclusion}

This study sought to describe the current status of eGovernment undertaken by government agencies in a local government. The results obtained are expected to be able to provide the government with a better understanding of what the government needs to do in terms of enhancing the e-Government utilization to the higher level. This will also better inform the government to make sure that they make the required resource distribution. In addition, the results show that the government has been trying to make sure that public institutions are more inclusive, effective, accountable and transparent through e-government implementation. However, in my opinion, the government should develop standards for agencies in terms of website design to optimize and promote the relationship between all stakeholders covering government itself, citizen, business, non profit, and employee, in support of sustainable development through the benefits offered by e-Government as suggested by The United Nations (EGovernment Survey, 2016). Although this study promises a pivotal contribution for academics and practitioners, this study produced somewhat limited findings because the author conducted the research only on agencies in a local government sphere, that is Pontianak Municipality. Therefore, it is highly recommended for further studies to do the research on a wider scope and more in-depth findings.

\section{References}

ASEAN. (2004). E-Readiness Assessment Guide: http://unpan1.un.org/intradoc/groups/public/docu mebts/APCITY?UNPAN007633.pdf. [Accessed on 12 January 2018].

Athmay et. al. (2016). E-Government Adoption and User's Satisfaction: An Empirical Investigation. EuroMed Journal of Business, Vol. 11, No. 1, pp. 23-30. 
Eliassen, Kjell A., \& Sitter, Nick. (2008). Understanding Public Management. London: SAGE Publications, Ltd.

Fan J. and Yang W. (2015). Study on E-Government Services Quality: The Integration of Online and Offline Services. Journal of Industrial Engineering and Management, Vol 8 (3), pp. 693718.

Fang, Zhiyuan. (2002). E-Government in Digital Era: Concept, Practice, and Development. International Journal of The Computer, The Internet and Management, Vol. 10, No. 2, pp. 122.

Forman, M. A. H. (2005). E-Government: Using IT to Transform the Effectiveness and Efficiency of Government. Available at http://go.worldbank.org/XDSYI1P0S0. [Accessed on 10 January 2018].

Graham, S. , \& Aurigi, A. (1997). Virtual Cities, Social Polarisation, and the Crisis in Urban Public Space. Journal of Urban Technology, Vol. 4 (1), pp. 19- 52 .

ITU. (2008). Report on Electronic Government for Developing Countries, International Telecommunication Union. Available at http://www.itu.int/ITU-D/cyb/app/docs/egov for dev countries-report.pdf. [Accessed 10 January 2018].

Law Number $11 / 2008$ on Electronic Information and Transaction (ITE)

Layne, K. \& Lee, J. (2001). Developing Fully Functional E-Government: A Four Stage Model. Germany: Government Information Quarterly.

Mayring. (2014). Qualitative Content Analysis: Theoretical Foundation, Basic Procedures And Software Solution. Available at http://nbnresolving.de/urn:nbn:de:0168-ssoar-395173.

[Accessed on 15 January 2018].

Mulgan, Geoff. (2014). Innovation in The Public Sector: How Can Public Organisations Better Create, Improve and Adapt?. Nesta, London.

Ndou. (2004). E -Government For Developing Countries: Opportunities And Challenges. The Electronic Journal on Information Systems in Developing Countries, Vol. 18 (1), pp. 1-24.

Parajuli. (2007). A Content Analysis of Selected Government Web Sites: a Case Study of Nepal. Electronic Journal of e-Government, Vol.5, Issue 1 , pp. $87-94$.

Presidential Instruction No. 6/2001 on a five-year National Information and Communications Technology Action Plan for Indonesia.

Presidential Decree No. 9/2003 on the ICT Coordinating Team (TKTI)

Presidential Instruction No. 3/2003 on National Policy on EGovernment Development

Reddick and Norris. (2013). E-participation in Local Governments: An Examination of PoliticalManagerial Support And Impacts. Transforming Government: People, Process and Policy, Vol. 7, No. 4, pp. 55-79.

Seifert, J.W. and Bonham, G.M. (2003). The Transformative Potential of E-Government in Transitional Democracies. Available at
http://faculty.maxwell.syr.edu/gmbonham/Transf ormative Potential of E-Government.pdf. [Accessed 4 February 2018].

Soliman, N. (2005). E-Readiness Assessment for Egypt. Available at http://www.wsisccra2005.gov.gh/conf updates.ht $\underline{\mathrm{m}}$. [Accessed on 20 January 2018].

Tsekos, Theodore. (2002). e-Government and The Transitional Countries. Available at http://unpan1.un.org/intradoc/groups/public/docu ments/UNTC/UNPAN003853.pdf [Accessed 25 January 2018].

UNASPA. (2001). Global Survey Of E-Government. Available

\section{at} http://www.unpan.org/egovernment2.asp. [Accessed on 20 January 2018].

Waheduzzaman, W., \& Miah, S.J. (2015). Readiness Assessment of E-government: a Developing Country Perspective. Transforming Government: People, Process and Policy, Vol. 9, No. 4, pp. 498-516.

Waller, L., \& Genius, A. (2015). Barriers to transforming government in Jamaica. Transforming Government: People, Process and Policy, Vol. 9 (4), pp. 480-497.

Wirtz, B., \& Kurtz O.T. (2016). Local E-Government and User Satisfaction With City Portals - The Citizens' Service Preference Perspective. The United States: Int Rev Public Nonprofit Mark, Springer. 